\title{
ASPECTOS IDEOLÓGICOS DA PEÇA PUBLICITÁRIA “NOVA PREVIDÊNCIA"
}

IDEOLOGICAL ASPECTS OF THE ADVERTISING PIECE "NOVA PREVIDÊNCIA"(NEW WELFARE)

ASPECTOS IDEOLÓGICOS DE LA PIEZA PUBLICITARIA “NOVA PREVIDÊNCIA”(NUEVA SEGURIDAD SOCIAL)

\author{
MARCIO GIUSTI TREVISOL ${ }^{1}$ \\ MARIA DE LOURDES PINTO DE ALMEIDA² \\ NATALIA OLEINICK ${ }^{3}$
}

Submissão: 26/10/2020

Aprovação: $1 / 12 / 2020$

Publicação: 21/12/2020

${ }^{1}$ Doutorando em Educação na Universidade de Passo Fundo. Mestre em Ética e Filosofia Política. Graduado em Filosofia pelo Centro Universitário Assunção. Atualmente é professor da Universidade do Oeste de Santa Catarina. ORCID iD: https://orcid.org/00000001-6127-1750. E-mail: marcio.trevisol@unoesc.edu.br.

2 Mestre e Doutora em Filosofia, História e Educação pela Unicamp. Graduada em Pedagogia e História. Pós-doc em Políticas Educacionais pela USP e em Política, Ciência e Tecnologia pela Unicamp. Docente do PPGEd da Unoesc, Joaçaba / SC. ORCID iD: https://orcid.org/0000-0001-8515-2908. E-mail: maria.almeida@unoesc.edu.br.

3 Graduada em Habilitação em Comunicação Social: Publicidade e Propaganda na Universiade do Oeste de Santa Catarina - Unoesc. Pesquisadora do grupo de pesquisa "Mídia, Comunicação e Sociedade". ORCID iD: https://orcid.org/0000-0001-8533-7857. Email: nataliaoleinick@gmail.com

\section{RESUMO}

O artigo é resultante da pesquisa que analisou a propaganda "Nova previdência", produzida e divulgada pelo governo brasileiro. Seu objetivo foi identificar os aspectos ideológicos e as intencionalidades presentes na campanha do governo sobre a reforma da previdência. A base epistemológica capturou Althusser (1970), o conceito de aparelhos ideológicos de Estado para a análise dos dados. Trata-se de pesquisa qualitativa e bibliográfica, de caráter exploratório. A técnica de análise é de conteúdo, tomando como base Bardin (2004) para a fundamentação das categorias de análise. Portanto, foi possível aferir que a peça publicitária "Nova previdência" é uma propaganda de governo que utiliza recursos 
ideológicos, como a neutralidade de classe social e a ideia de patriotismo, a fim de produzir nos cidadãos um sentimento de apoio à reforma.

Palavras-chave: Ideologia. Senso Comum. Patriotismo. Reforma da Previdência. Propaganda de governo.

\section{ABSTRACT}

The article is the result of a research that analyzed the "Nova previdência" (New Welfare) advertisement produced and disclosed by the Brazilian government. Its objective was to identify the ideological aspects and the intentionalities present in the government's campaign on welfare reform. The epistemological basis included Althusser (1970), who lends the concepts of state ideological apparatuses for the data analysis. This is a qualitative, exploratory, and bibliographical research. The analysis technique is of content, taking Bardin (2004) as the basis for the rationale of the categories of analysis. Therefore, it was possible to ascertain that the publicity piece "Nova previdência" is a government propaganda that uses ideological resources, such as social class neutrality and the idea of patriotism, in order to produce, in the citizens, a feeling of support for the reform.

Keywords: Ideology. Common Sense. Patriotism. Welfare Reform. Government Propaganda.

\section{RESUMEN}

El artículo es el resultado de la investigación que analizó la propaganda "Nova previdência" producida y difundida por el gobierno brasileño. Su objetivo fue identificar los aspectos ideológicos y las intenciones presentes en la campaña del gobierno sobre la reforma de la seguridad social. La base epistemológica comprendió Althusser (1970), que presta los conceptos de aparatos estatales ideológicos para el análisis de datos. Se trata de una investigación cualitativa, bibliográfica, de carácter exploratorio. La técnica de análisis es de contenido, basado en Bardin (2004) para la fundamentación de las categorías de análisis. Por lo tanto, fue posible medir que la pieza publicitaria "Nova previdência" es un anuncio del gobierno que utiliza recursos ideológicos, como la neutralidad de la clase social y la idea del patriotismo, con el fin de producir en los ciudadanos un sentimiento de apoyo a la reforma.

Palabras-clave: Ideología. Sentido común. Patriotismo. Reforma de la seguridad social. Propaganda del gobierno. 


\section{INTRODUÇÃO}

A partir da segunda guerra mundial, as propagandas de governo ganharam força e destaque, uma vez que a publicidade passa a ser vista pelos governos como importante ferramenta de divulgação e visibilidade para seus atos. As propagandas tinham como objetivo identificar e aglutinar forças em torno de um ideal ou produzir um sentimento de aprovação das ações governamentais. Nesse sentido, a propaganda de governo, desde a grande guerra, apresenta-se como ferramenta potente.

Diante dessa conjuntura, a tese que se buscou investigar teve como premissa: quais as intencionalidades e sentidos ideológicos da peça publicitária "Nova Previdência" de 2019? Para responder a essa inquietação, apresentou-se os seguintes objetivos: a) identificar os aspectos ideológicos, a partir de categorias de análise, que estão presentes na propaganda de governo e que possuem como interesse formar uma opinião pública favorável à reforma da previdência social de 2019 no Brasil; b) pontuar os interesses e intencionalidades da propaganda do governo; c) discutir os aspectos ideológicos que a propaganda utiliza para produzir uma opinião pública favorável à reforma de previdência; d) apresentar o contexto social que levou à elaboração da peça publicitária pelo governo. Para responder aos objetivos e ao problema investigativo utilizou-se pesquisa qualitativa e de caráter exploratório. O universo da pesquisa é a peça publicitária "Nova Previdência". A técnica utilizada foi a análise de conteúdo de Bardin (2004), tomando como ponto de partida duas categorias de análise - Senso comum e ideologia; e ideologia e patriotismo, fundamentadas a partir dos autores Loius Althusser (1970), John Thompson (1998) e Chauí (2017).

$\mathrm{O}$ artigo apresenta-se em duas partes: $\mathrm{Na}$ primeira, aborda-se o conceito de propaganda de governo, tomando como referencial epistemológico Althusser (1970), com o conceito de aparelhos ideológicos de Estado. Na segunda parte do trabalho, analisam-se, à luz das categorias de análise, quais os sentidos ideológicos que a peça publicitária "Nova Previdência" pretendeu produzir para os receptores da mensagem, sendo essa a população em geral com foco na classe trabalhadora, que é a mais afetada pelos resultados da Reforma 
da Previdência. A escolha da peça publicitária "Nova Previdência" justifica-se por ser um dos primeiros atos do Presidente da República referentes as reformas.

\section{IDEOLOGIA E GOVERNO: APROXIMAÇÕES CONCEITUAIS}

Para principiar, adota-se aqui a definição de propaganda proposta por Chauí (2017). Para a autora, a palavra 'propaganda` deriva do verbo 'propagar’, que significa `multiplicar por meio da reprodução, espalhar-se por um território`. A propaganda é uma difusão e uma divulgação de ideias, valores, opiniões, informações para o maior número de pessoas. É por isso que se fala em propaganda religiosa, comercial ou política. A propaganda sempre pretende se dirigir publicamente para um grande número de pessoas no intuito de informar ou produzir determinado sentido em torno de um tema, ou mesmo de um produto.

De acordo com Chaú (2017, p. 38), “a propaganda opera por meio de: 1) explicações simplificadas e elogios exagerados sobre os produtos; 2) slogans curtos que possam ser facilmente memorizados e; 3) aparente informação e prestação de serviços." Para ser eficaz, a propaganda precisa satisfazer duas condições básicas Da mesma forma, também governos e instituições públicas se utilizam de propagandas para divulgar e informar a população. O campo de pesquisa da propaganda política é altamente fecundo e com uma produção considerável. Dentre os pesquisadores, Althusser (1970) merece destaque, ao elaborar a teoria dos aparelhos ideológicos de Estado.

Os aparelhos ideológicos de Estado, pontuados por Althusser, passam por várias instituições, como a escola, a igreja e até mesmo a própria família. A escola, primordialmente, é um regulador das massas, de forma que o ensino utilizado pode preparar a população para servir como mão de obra ao mercado de trabalho, comercial e industrial. Althusser (1970, p. 59) explica:

A reprodução da força de trabalho tem pois como condição sine qua non, não só a reprodução da "qualificação" desta força de trabalho, mas também a reprodução da sua sujeição à ideologia dominante ou da "prática" desta ideologia, com tal precisão que não basta dizer: "não só, mas também", pois conclui-se que é nas formas e sob as formas da sujeição ideológica que é assegurada a reprodução da qualificação da força de trabalho. Mas, aqui reconhece-se a presença eficaz de uma nova realidade: a ideologia. 
As instituições assumiram um papel de controle, onde a ideologia da alta burguesia mantém a classe proletária submissa e sem deter qualquer domínio econômico e político. Não se pode controlar esse domínio sobre nossas próprias vidas, quanto mais impactar na sociedade a partir dele. Contudo há de se considerar, que a ideologia, a maneira de Gramsci (1999), possuem um sentido positivo. A ideologia no entendimento do autor também pode revelar uma consciência de mundo ou uma perspectiva hegemônica de libertação de condições de controle e dominação. O processo de consolidação de uma ideologia condizente com as condições materiais da classe social é decorrente do trabalho dos intelectuais orgânicos. A ideologia, neste sentido, ligado a práxis social tornasse condição de libertação.

O Estado é um organismo com uma complexa distribuição de necessidades para que seu funcionamento ocorra corretamente. Segundo Althusser (1970, p. 62):

O Estado é uma "máquina" de repressão que permite às classes dominantes (no século XIX à classe burguesa e à "classe" dos proprietários de terras) assegurar a sua dominação sobre a classe operária para submetê-la ao processo de extorsão da mais-valia (quer dizer, à exploração capitalista). O Estado é então e antes de mais aquilo a que os clássicos do marxismo chamaram o aparelho de Estado.

Para este autor, os aparelhos de Estado podem ser repressivos ou ideológicos. O aparelho repressivo de Estado tem a intenção de manter o controle social de acordo com a segurança dos interesses do aparelho estatal e das pessoas que detêm maior poder dentro dele. Um Estado repressivo trabalha com aparatos não apenas ideológicos, mas com repressão e apologia à violência, que não necessariamente precisa ser física ou fazer alusão à tortura.

Embora seja importante compreender como os mecanismos de controle repressivo são formados, o interesse de pesquisa recai sobre os aparelhos ideológicos de Estado. Segundo Althusser (1970), a reprodução da força de trabalho não exige somente a reprodução de sua qualificação, mas ao mesmo tempo numa reprodução de sua submissão às normas da ordem vigente, isto é, uma reprodução da submissão dos operários e uma reprodução da capacidade de perfeito domínio da ideologia dominante por parte dos 
agentes da exploração e repressão, de modo a que eles assegurem também, "pela palavra", o predomínio da classe dominante. Para Althusser (1970, p. 91),

\begin{abstract}
A ideologia da ideologia reconhece, apesar de sua deformação imaginária, que as "ideias" de um sujeito humano existem em seus atos, ou devem existir em seus atos, e se isso não ocorre, ela lhe confere ideais correspondentes são atos (mesmo perversos) que ele realiza. Esta ideologia fala de atos: nós falaremos de atos inscritos em práticas.
\end{abstract}

Neste sentido, a ideologia não é ver um "reflexo" social ou do pensamento do indivíduo. Os aparelhos ideológicos de Estado são descritos por Althusser (1970, p. 68), como "AIE religiosos (o sistema das diferentes Igrejas), AIE escolar (o sistema das diferentes "escolas" públicas e privadas), AIE familiar, AIE político (o sistema político, os diferentes partidos), AIE sindical e AIE de informação (a imprensa, rádio, a televisão, etc.), AIE cultural (Letras, Belas Artes, esportes, etc.)".

Alguns aspectos diferenciam os aparelhos repressivos de Estado dos aparelhos ideológicos de Estado, dentre suas diferenças destacam-se: primeiro, para cada aparelho repressivo de Estado existe uma pluralidade de aparelhos ideológicos de Estado. Enquanto os aparelhos repressivos são exclusivos e legalmente pertencentes ao Estado e à esfera pública, os aparelhos ideológicos de Estado fazem parte tanto da esfera pública quanto da esfera privada. As igrejas, os partidos políticos, os sindicatos, as famílias, algumas escolas e universidades, a maioria dos jornais, as empresas de comunicação e culturais, etc., são de ordem privada. Por fim, a principal diferença consiste, para Althusser (1970, p. 69), na seguinte definição: "enquanto o Aparelho Repressivo de Estado funciona através da violência ao passo que os Aparelhos Ideológicos de Estado funcionam através da ideologia".

A ideologia é apresentada por Althusser a partir de duas teses. Na primeira tese, (ALTHUSSER, 1970, p. 85), “A ideologia representa a relação imaginária dos indivíduos com suas condições reais de existência.” Na segunda tese (ALTHUSSER, 1970, p. 88), “a ideologia tem uma existência material." Na primeira tese, o autor apresenta argumentos sólidos e positivos da ideologia. Recorrendo a Gramsci, argumenta que a ideológica é um conjunto de ideias, valores e símbolos que se constituem como um componente da luta de 
classes e serve para caracterizar um grupo ou movimento social. Na segunda tese, apresenta o caráter negativo da ideologia. Esse aspecto para a presente análise é o mais importante, porque permite compreender como certas instituições privadas ou públicas atuam na produção de valores e ideais que retiram a capacidade analítica e de consciência de classe dos sujeitos.

A materialidade da ideologia é expressa da seguinte forma por Althusser (1970, p. 92):

\footnotetext{
O sujeito, portanto, atua enquanto agente do seguinte sistema (enunciado em que sua ordem de determinação real): a ideologia existe em um aparelho ideológico material, que prescreve práticas materiais reguladas por um ritual material, práticas estas que existem nos atos materiais de um sujeito, que age conscientemente segundo sua crença.
}

A estrutura da ideologia é produzir nos sujeitos certas concepções e ideias que nem sempre são condizentes com sua realidade. É nesse sentido, que o objeto de investigação desta pesquisa compreende os aspectos ideológicos da peça publicitária "Nova previdência”. Em que medida o aparelho ideológico do Estado brasileiro, por meio da comunicação, pretende produzir um sentido sobre a previdência social nos cidadãos. Essa condição discute-se na próxima seção.

\section{UNIVERSO DA PESQUISA, PROCEDIMENTOS METODOLÓGICOS E} ANÁLISE DOS DADOS

O universo da pesquisa é a propaganda de governo "Nova previdência", lançada pelo canal do Governo do Brasil no YouTube, no dia 14 de março de 2019. A campanha "É para todos, é melhor para o Brasil" visa defender as decisões tomadas sobre a reforma e convencer o espectador de que a reforma é útil e necessária para o país. A campanha é composta por mais peças de campanha informativa, as quais explicam suas bases e orientações. A campanha foi desenvolvida pela Secretaria Especial de Comunicação Social da Presidência da República (Secom) e executada pela agência de publicidade Artplan. Todas as peças de audiovisual podem ser encontradas no YouTube, no canal oficial do 
governo do Brasil, ou no site brasil.gov.br/novaprevidencia/. A reforma da previdência social trata-se da reformulação das convenções sociais que afetam o bem-estar da população, em que todo cidadão recebe o direito ao amparo do governo em situações, como velhice, invalidez, doenças e afins. Esse auxílio do governo é garantido por lei e ampara o trabalhador que esteja impossibilitado de exercer sua função. Por outro, o governo defende a reforma da previdência a partir de dois argumentamos básicos, a saber, crescimento da despesa previdenciária e o processo de envelhecimento da população. Os dois argumentos combinados sustentam que o país não terá condições de arcar com os custos das aposentadorias ao longo prazo.

A pesquisa verifica, à luz dos conceitos empregados por Althusser (1970), Chauí (2017) e Thompson (1998), quais os recursos ideológicos utilizados na propaganda de governo para produzir uma opinião pública favorável à reforma da previdência. O procedimento metodológico utilizado foi a análise de conteúdo de Bardin (2004, p. 142).

Em conclusão, pode dizer-se que o que caracteriza a análise qualitativa é o facto de a interferência - sempre que é realizada - ser fundada na presença do índice (tema, palavra, personagem, etc.!) e não sobre a frequência de sua aparição, em cada comunicação individual.

A análise do conteúdo permite verificar e pontuar quais elementos significativos estão presentes na propaganda de governo. Em decorrência da técnica de análise de conteúdo foram elaboradas duas categorias de análise que permitem classificar e agrupar as falas e imagens de acordo com sua significação e intencionalidade. 


\begin{tabular}{|l|l|}
\hline Categoria & Descrição \\
\hline Ideologia e Senso comum $^{4}$ & $\begin{array}{l}\text { A ideologia apaga a historicidade e a luta de classes, ideologia como uma } \\
\text { representação imaginária dos indivíduos com suas condições reais de } \\
\text { existência, ideologia com superestrutura e a materialização de interesses } \\
\text { de classes (ALTHUSSER, 1970). Inversão da realidade, alienação, } \\
\text { dissimulação da realidade (CHAUÍ, 2017). Sentido, ideias, controle, } \\
\text { manipulação e dominação (THOMPSON, 2011) e de senso comum de } \\
\text { Perelman (2014). }\end{array}$ \\
\hline Ideologia e patriotismo $^{5}$ & $\begin{array}{l}\text { Sentido de lealdade à nação, sacrifício para a nação, identidade, coesão } \\
\text { social, referenciais de vida comum, comprometimento, amor à pátria, } \\
\text { união e igualdade. Poder simbólico (THOMPSON, 1998) e Kujawski } \\
\text { (1997). }\end{array}$ \\
\hline
\end{tabular}

Quadro 1 - Categorias de análise. Fonte: os autores.

Esta análise inicia-se com o objetivo de compreender que qualquer mensagem repassada, seja de forma textual possui um caráter carregada de ideologia 6 . Dentro da peça publicitária analisada, o texto é um dos artifícios apresentados, sendo importante para que a mensagem seja repassada ao receptor de forma clara e objetiva. As fontes simples de fácil leitura e a linguagem coloquial auxiliam a compreensão e conectam o público à mensagem por meio da identificação linguística. A categoria de análise Ideologia e Senso comum é verificada nas seguintes partes da peça publicitária, a saber:

\footnotetext{
${ }^{4}$ Utilizamos no artigo a concepção de senso comum desenvolvida pelo filósofo belga Chaim Perelman (19121984), que definiu o senso comum como uma série de crenças admitidas por determinado grupo social. O senso comum pode ser definido como um tipo de conhecimento que orienta a vida social. É coletivo e partilhado por gerações, no entanto, carece de criticidade, sistematicidade e profundidade.

${ }^{5}$ A partir de Kujawski (1997), no livro Patriotismo e nacionalismo, define-se Patriotismo como amor à pátria. Portanto, o autor defende que o sentimento patriótico nos leva a defender e exaltar características tidas como boas da cultura de sua nacionalidade. Daí defendemos todas as partes da nação, a partir da criação desse sentimento.

${ }^{6}$ Para aprofundar os estudos e a análise sugerimos a leitura do livro 'Marxismo e filosofia da linguagem: problemas fundamentais do método sociológico na ciência', de autoria de Bakhtin.
} 


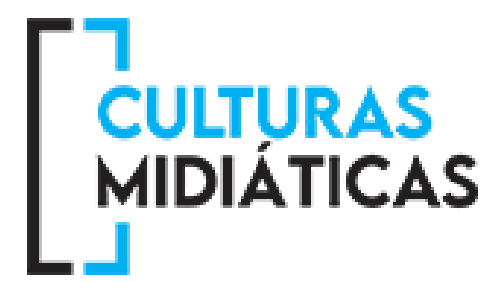

REVISTA DO PROGRAMADE

PÓS-GRADUAÇÃO EM COMUNICAÇÃO DA

UNIVERSIDADE FEDERAL DA PARAIBAA

ISSN 1983-5930

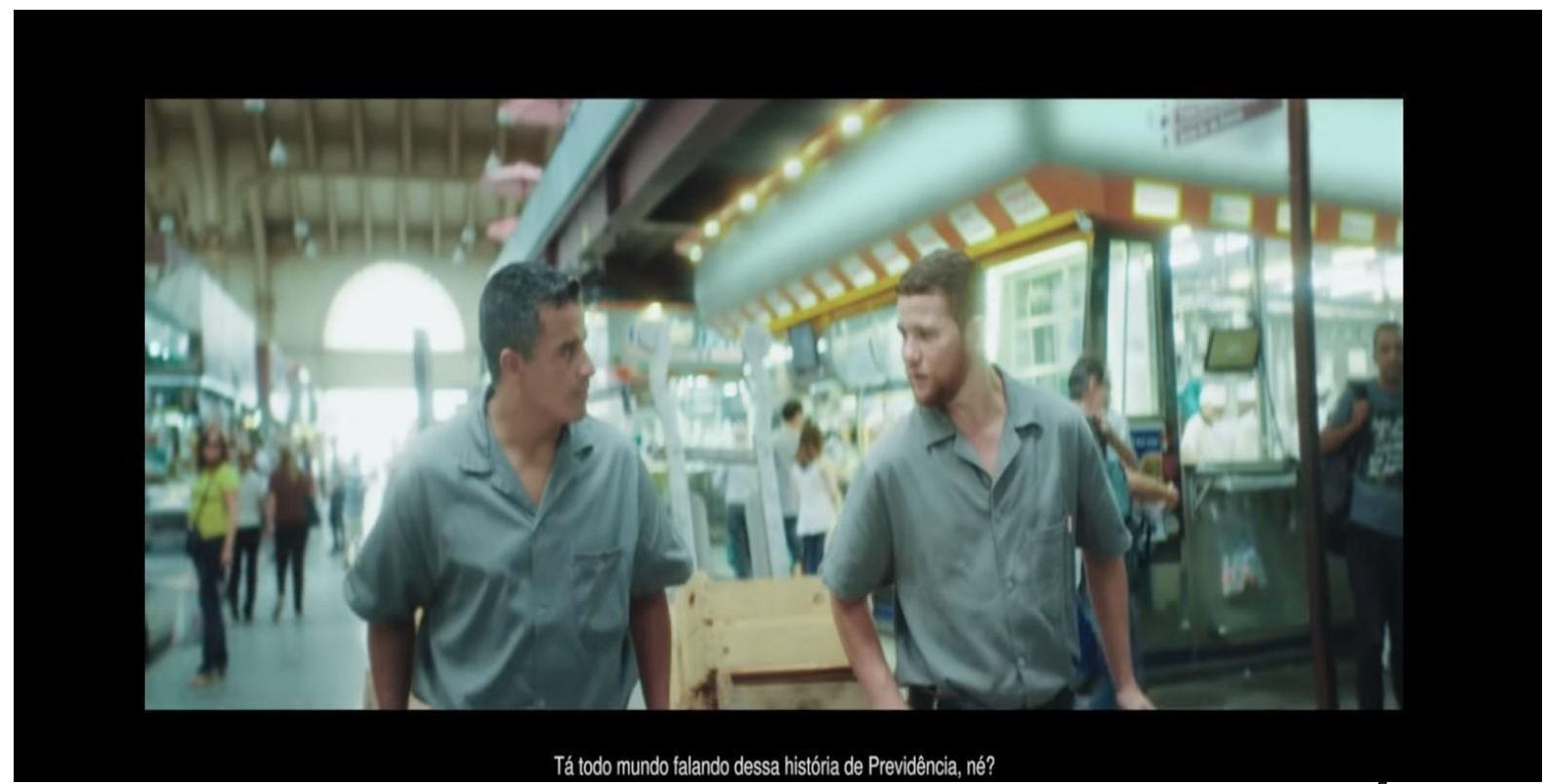

Frame 1 - Apresentação do tema dentro do audiovisual (Tempo: 00:00:02). Fonte: YouTube (2019).

Inicia-se o conteúdo textual da peça com a afirmação de que está todo mundo falando sobre a reforma da previdência e, em seguida, confirmando com o colega a partir do questionamento "né?", o personagem tem a clara intenção de introduzir o assunto como se este fosse algo comum e consenso entre todos. Que a reforma é de conhecimento público. A identidade visual da propaganda captura um local de trabalho, especificamente, um mercado público. Sua intenção é demostrar que todos estão falando sobre a reforma da previdência, que ela é necessária e que é aceita por todos. O objetivo é apagar o discurso que afirmava que a reforma da previdência prejudicava o trabalhador. De acordo com Chauí (2013), a propaganda leva a uma inversão da realidade e uma dissimulação da realidade, ao propor que todos são conhecedores da reforma da previdência. A expressão "né" afirma um sentido universal que todos os brasileiros estão informados.

\footnotetext{
${ }^{7}$ Disponível em: https://youtu.be/P0whGOzKzhk. Acesso em: 22 out. 2019.
} 


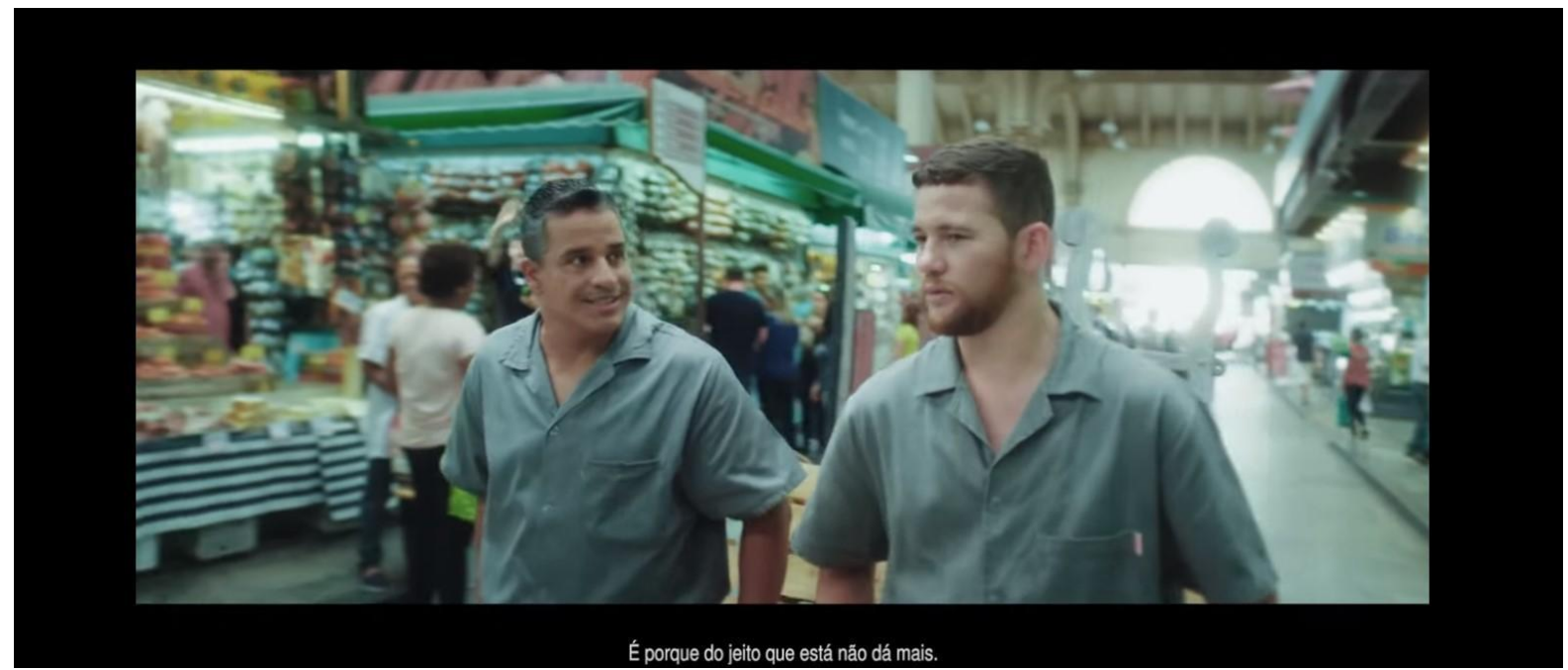

Frame 2 - Apresentação do tema dentro do audiovisual (Tempo: 00:00:04). Fonte: YouTube (2019).

O segundo slide expressa a ideia que a própria classe trabalhadora deveria concorda com a reforma da previdência, sem nenhuma restrição ou questionamento. A fala "É porque do jeito que está não dá mais" revela uma dissimulação da realidade. Segundo os dados da Folha (2019), a reforma da previdência proposta pelo governo é rejeitada por $51 \%$ dos brasileiros, mostra a pesquisa Datafolha. São favoráveis $41 \%$, $2 \%$ se dizem indiferentes e $7 \%$ não sabem. A peça publicitária pretende trazer um sentido de aprovação e aceitação por parte da população. A intenção é produzir um consenso sem restrições ou conflitos. Para Thompson (1998, p. 24):

Os indivíduos se ocupam constantemente com as atividades de expressão de si mesmos em formas simbólicas ou de interpretação das expressões usadas pelos outros; eles são continuamente envolvidos na comunicação uns com os outros e na troca de informações de conteúdo simbólico.

O simbolismo, apresentado pelo autor, é verificado nas cores e na distribuição dos personagens. A mídia possui um poder simbólico de ensinar como as pessoas devem pensar e agir. No caso da propaganda, os valores simbólicos atuam pedagogicamente, no intuito de produzir a aceitação da mudança. Para Garcia (1999, p. 17):

Não é mais tão fácil perceber que se trata de propaganda e que há pessoas tentando convencer outras a se comportarem de determinada maneira. As ideias difundidas nem sempre deixam transparecer sua origem nem os objetivos a que se destina. Por trás delas, contudo, existem sempre certos grupos que precisam do 
apoio e participação de outros para a realização de seus intentos e, com esse objetivo, procuram persuadi-los agir numa certa direção.

O senso comum pode ser descrito como algo que deve ser identificado sobre o desejo de que todos sejam convencidos de que a mudança é necessária para um bem maior. Todo grupo dispõe de ideologias que servem para que seu papel social seja preenchido, em que cada um se faz obedecer ao mesmo tempo. Essa aprendizagem dos costumes da burguesia nos remete a certas crenças e tradições que acabaram sendo aderidas para o melhor funcionamento da sociedade capitalista.

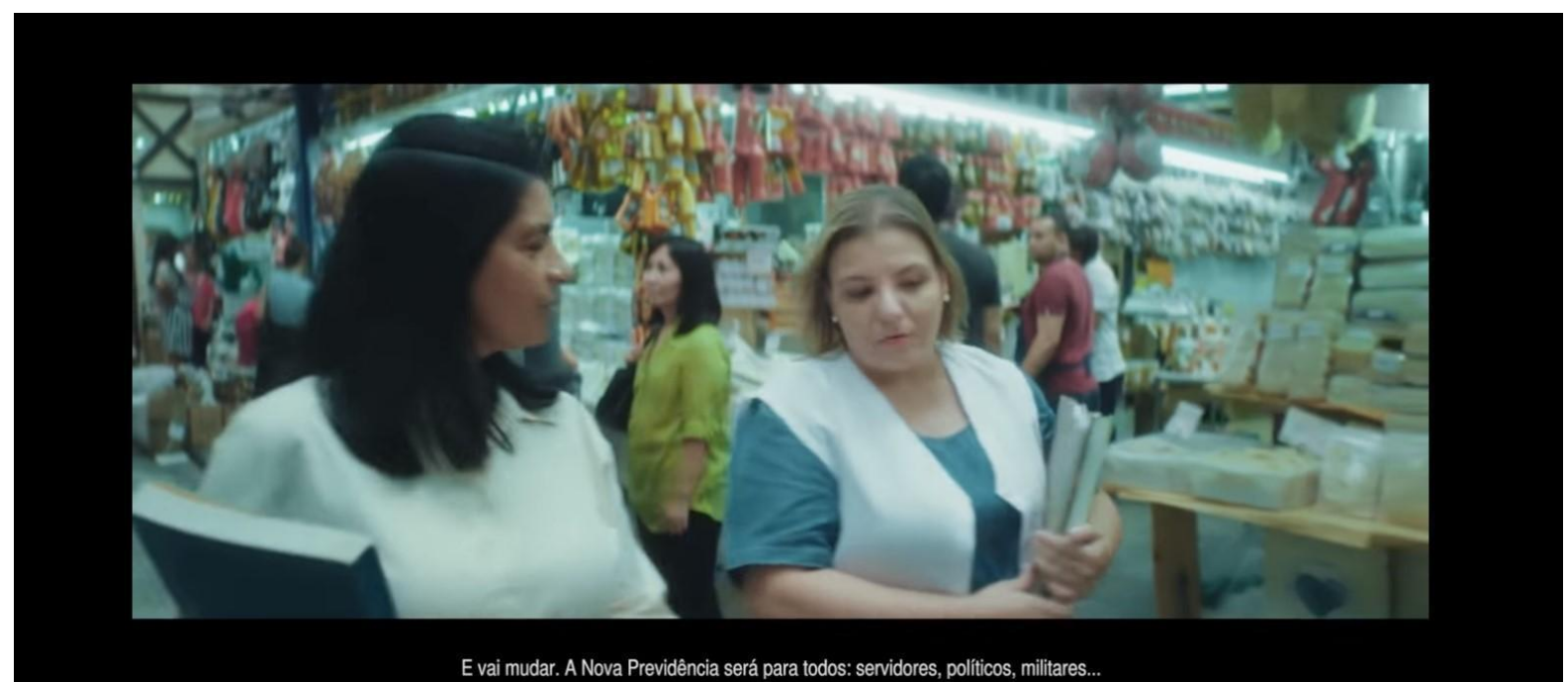

Frame 3 - Apresentação do tema dentro do audiovisual (Tempo: 00:00:06). Fonte: YouTube (2019).

Na expressão "E vai mudar. A Nova Previdência será para todos: Servidores, políticos, militares...”, a narração é feita por personagens populares. A afirmação de que essa mudança não privilegiará nenhuma classe e, dessa forma, todos podem se sentir seguros, apoiando a reforma da previdência. Ademais, é importante destacar que as duas personagens da propaganda carregam livros, as roupas definem as personagens como trabalhadoras e a cor da pele pretende transmitir a diversidade étnica. A pretensão é apagar a desigualdade social no Brasil e a historicidade da luta de classe. Ideologicamente, transmite um senso comum, ao tratar a reforma da previdência como igualitária a todas as 


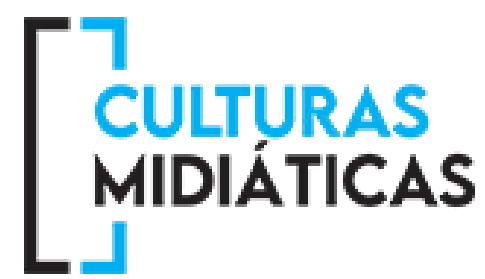

REVISTA DO PROGRAMADE

PÓS-GRADUAÇÃO EM COMUNICAÇÃO DA

UNIVERSIDADE FEDERAL DA PARAIBA

ISSN 1983-5930

categorias de trabalhadores e classes sociais. Althusser (1970) auxilia no entendimento a essa questão, ao propor que o Estado é um aparelho que se define na luta de classes.

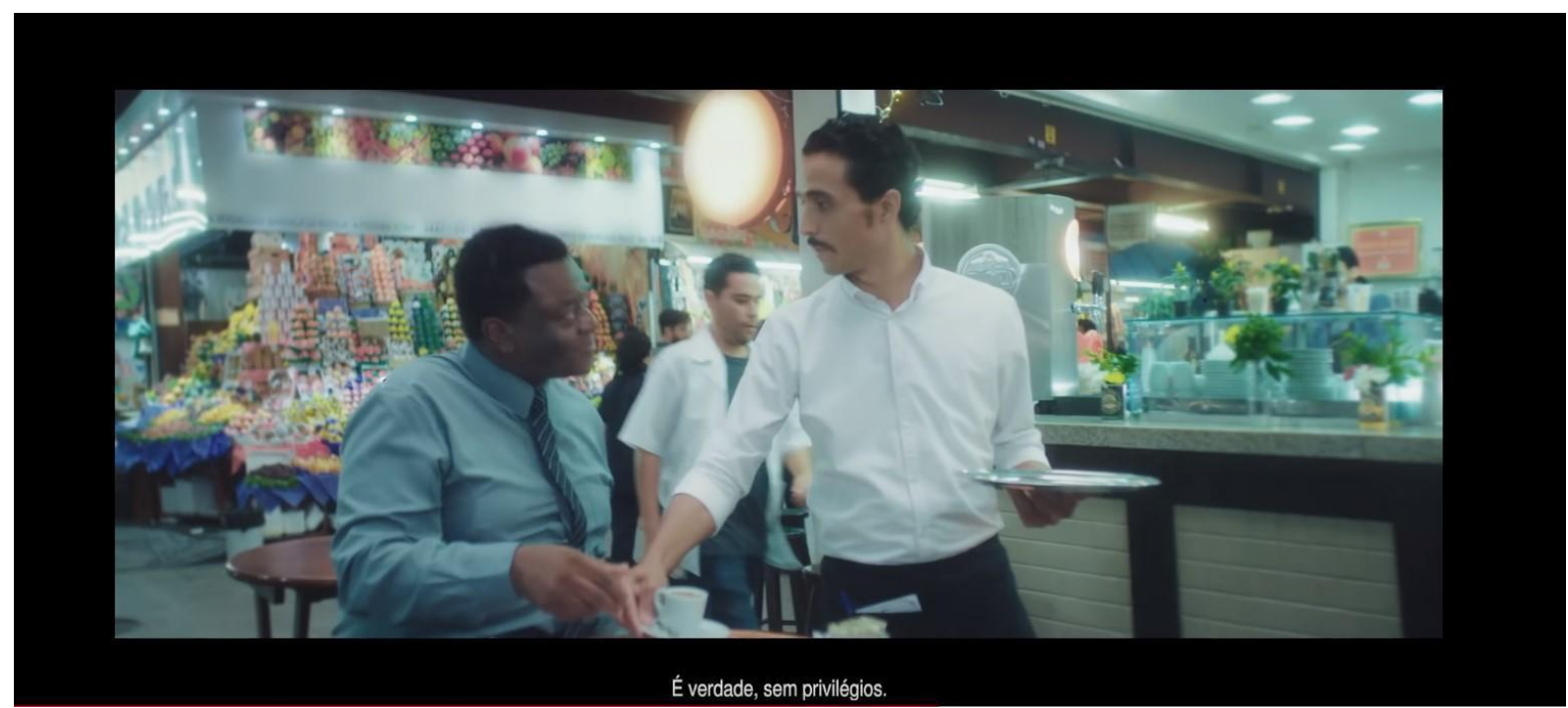

Frame 4 - Apresentação do tema dentro do audiovisual (Tempo: 00:00:17). Fonte: YouTube (2019).

No slide analisado, ideologia tem destaque, pois para que o receptor da mensagem concorde com o conteúdo, é mais interessante para o Estado brasileiro que ele se identifique, de forma a aceitar com maior facilidade o recado repassado. Althusser (1970, p. 85) traz a afirmação de que a "ideologia é apenas uma representação que o indivíduo cria, não necessariamente condiz com suas condições reais de existência." Essa seletividade o enquadra dentro da classificação de senso comum, em que sua ideologia tenta se aplicar ao cotidiano, gerando uma ideia de igualdade e inclusão social. A fala "Quem ganha menos vai pagar menos. E quem ganha mais, vai pagar mais" é uma clara expressão ideológica e um sentido em que as classes menos favorecidas devem se sentir acolhidas e respeitadas. A reprodução das relações de produção é assegurada pela questão da superestrutura.

Quanto à categoria ideologia e patriotismo, esta foi identificada nos seguintes trechos da peça publicitária. 

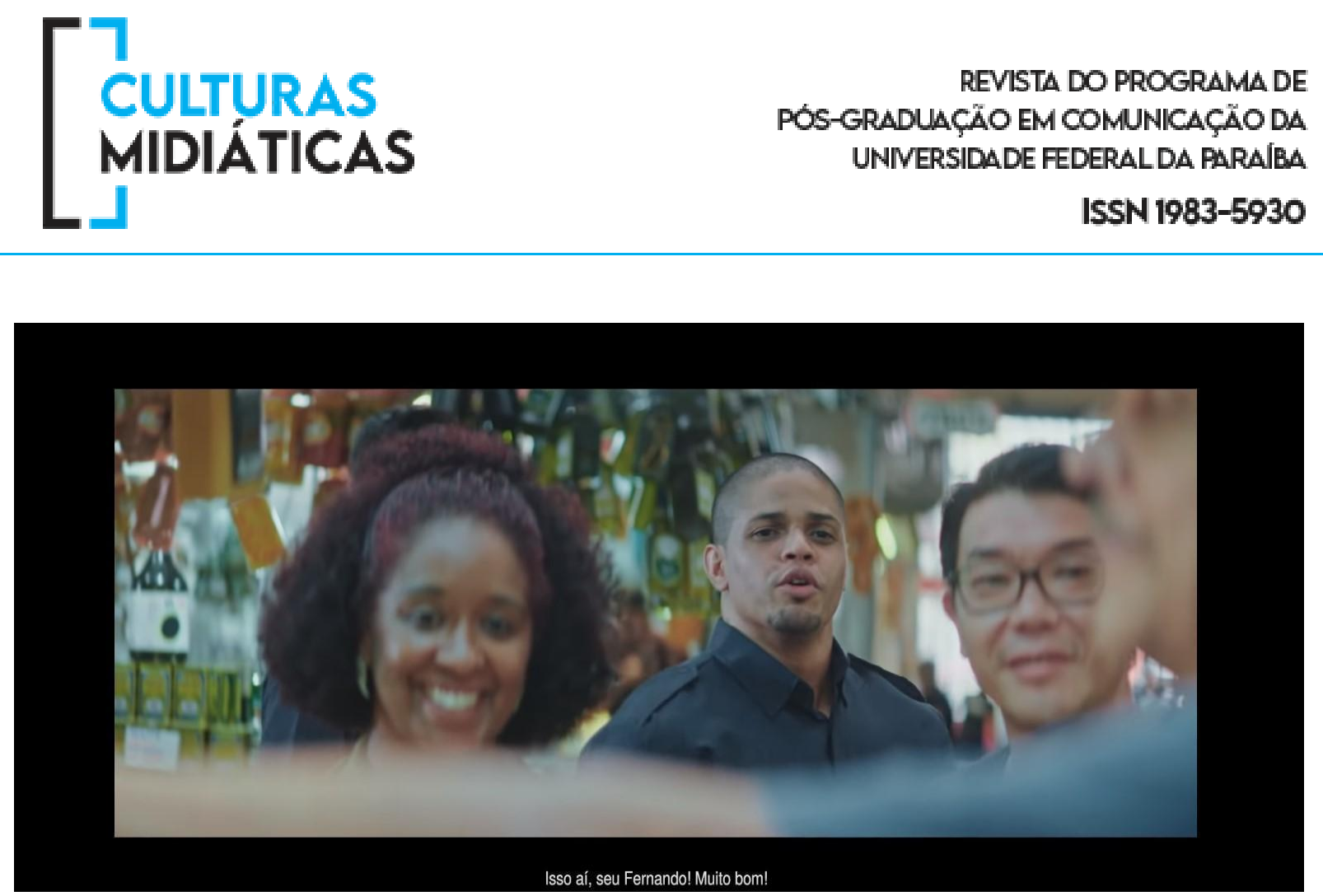

Frame 5 - Apresentação do tema dentro do audiovisual (Tempo: 00:00:23). Fonte: YouTube (2019).

A presente afirmação de concordância durante o vídeo tem a função de demonstrar um apoio à reforma. A própria imagem traduz um sentido de patriotismo e identidade. A propaganda pretende, por meio do simbolismo, expressar o ideal - todo o brasileiro que ama o país deve aceitar a reforma da previdência. Esse tipo de ideal, apoiado nessa perspectiva, foi amplamente explicado por Garcia (1999), no livro Propaganda ideológica: ideologia e manipulação. Na obra, o autor apresenta como o governo brasileiro, durante a ditadura militar de 1964, utilizou as propagandas que enalteciam o sentimento patriótico para dissimular a realidade social de opressão e controle social. 


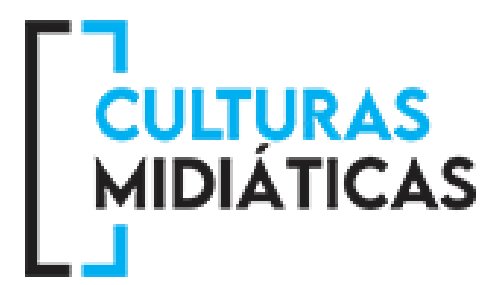

REVISTA DO PROGRAMADE

POS-GRADUAÇÃO EM COMUNICAÇÃO DA

UNIVERSIDADE FEDERALDA PARAÍBA

ISSN 1983-5930

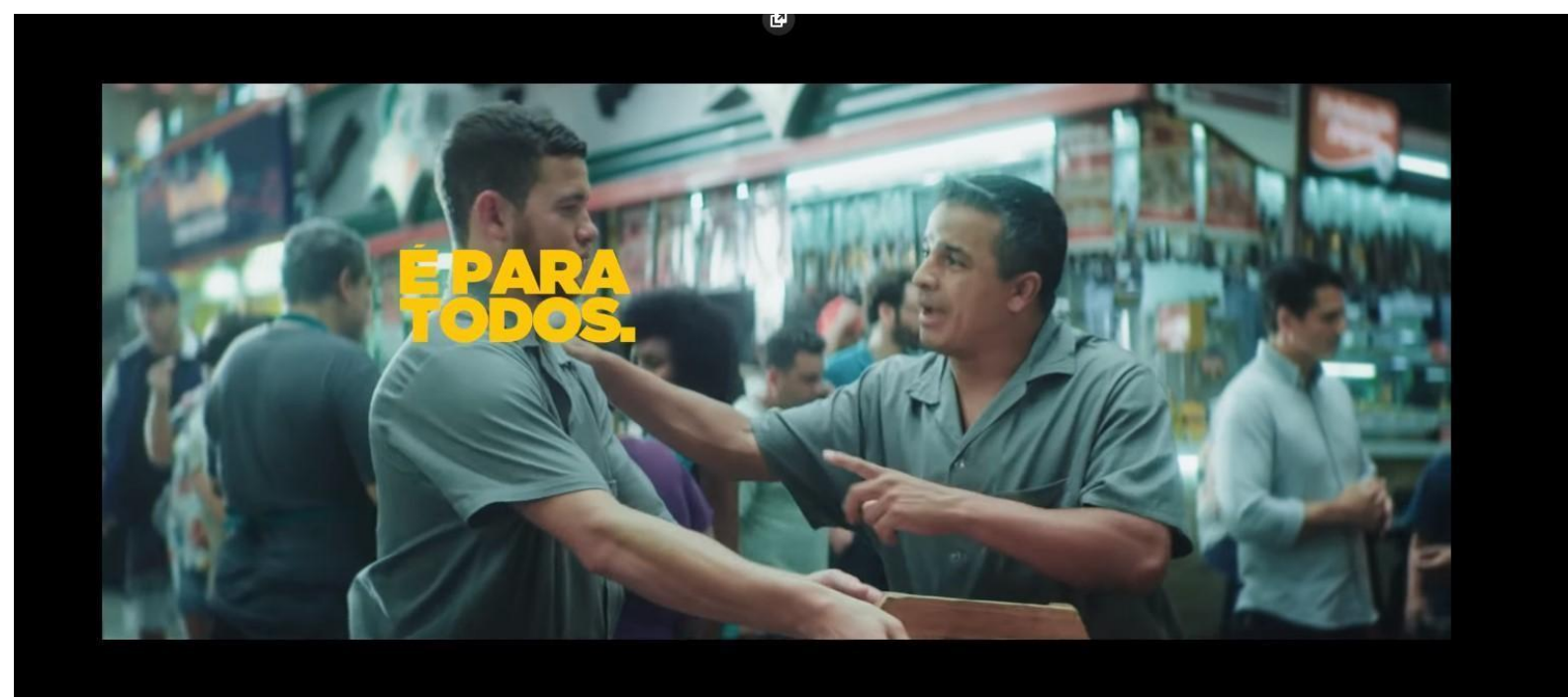

Frame 6 - Apresentação do tema dentro do audiovisual (Tempo: 00:00:26) Fonte: YouTube (2019).

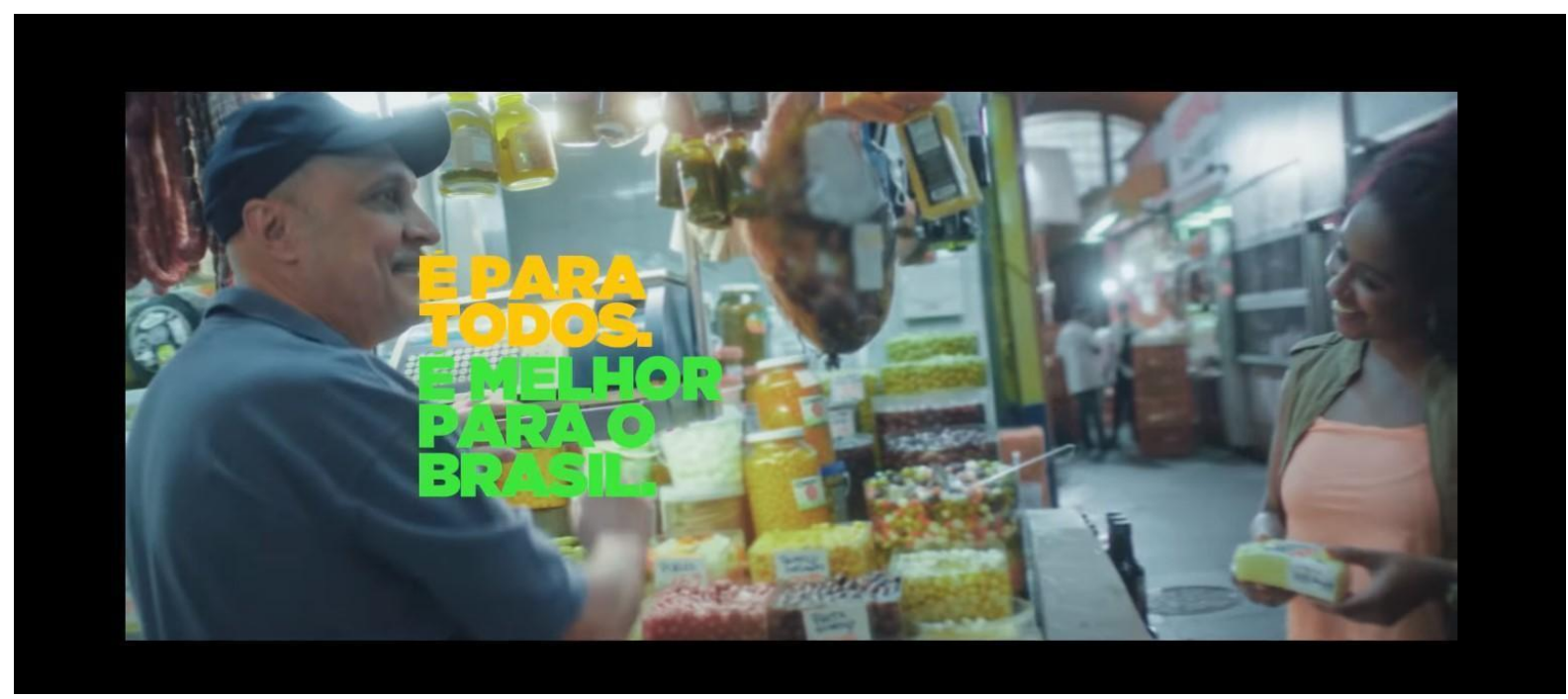

Frame 7 - Apresentação do tema dentro do audiovisual (Tempo: 00:00:27). Fonte: YouTube (2019).

Os frames 6 e 7 são classificados na categoria ideologia e patriotismo. Em ambos, o desejo é afirmar que a reforma da previdência social é o melhor para o Brasil. Contudo, sua estratégia é produzir, por meio de simbolismos, um sentimento de lealdade à nação, uma identidade e um comprometimento com o futuro da nação, mesmo que isso signifique assumir dificuldades e sacrifícios. Existe aqui a necessidade da universalização da 
expressão de que a reforma é uma vantagem para o país e que, dessa forma, todos serão beneficiados. No semblante dos personagens percebe-se uma expressão de felicidade, juntamente com uma postura corporal que expressa consentimento diante da informação recebida. Para Ribeiro Branco (2015, p. 78):

O problema não se concentra apenas na exclusão, mas também na exploração dos trabalhadores. $\mathrm{O}$ grande número de horas trabalhadas, com uma alta exigência de produção, baixos salários e poucas condições de vida, tem destruído a dignidade humana.

Existe uma urgência de mudança para que as classes trabalhadoras iniciem um processo de evolução e sejam beneficiadas por seus sacrifícios. A proposta de ideologia repassada aqui é de controle. Dentro da ideologia do patriotismo encontram-se as ferramentas para convencer o sujeito de que se ele quer o melhor para seu país, deve concordar.

É importante ainda fazer a menção, que no final da peça publicitária, a expressão "Pátria Amada" é apresentada. A própria marca do governo eleito no pleito eleitoral de 2017 é patriótica. Seu frame Pátria Amada busca reafirmar o sentimento patriótico como condição de construção de um país desenvolvido e competitivo. No entanto, é um senso comum à medida que o amor extremado alimenta o ódio e cega a análise crítica das condições sociais.

\section{CONSIDERAÇÕES FINAIS}

Os conceitos apresentados pelos atores, sobretudo, os conceitos de aparelhos ideológicos de Estado, de Althusser (1970), o conceito de ideologia, de Chauí (2017) e de poder simbólico, de Thompson (1998), permitem tecer uma análise da propaganda de governo "Nova Previdência". O contexto do Estado brasileiro de crise, nas áreas da política e da economia, fez com que o governo adotasse medidas de austeridade que são impopulares. Diante de tal condição, o governo lançou um conjunto de discursos que

justificavam a saída da crise econômica com as reformas de Estado, em especial, a necessidade de reformular o modelo previdenciário. 
O fato é que reformas desse tipo não são fáceis e precisam do apoio popular opinião pública favorável. É nesta perspectiva, que a campanha publicitária da "Nova Previdência" é utilizada como ferramenta de convencimento. Não se trata de uma campanha informativa, mas de uma campanha de convencimento, que não deixa margens para questionamentos dos receptores. Para convencer, é necessário construir uma narrativa, um simbolismo e um conjunto argumentativo que tenha persuasão sem explicar, isto é, que por mecanismos ideológicos e de valores desassociados ao contexto histórico e social, produza nos sujeitos um sentimento de aceitação. Cabe ressaltar, que a intenção desta pesquisa não é analisar a viabilidade ou a justificativa da reforma da previdência, mas identificar os elementos ideológicos ou simbólicos utilizados na campanha, os quais são utilizados como justificativa para as intenções governamentais e funcionam como manobra de massa diante das classes sociais menos favorecidas.

Nesse sentido, a campanha utiliza as duas categorias ideológicas: de senso comum e de patriotismo. Nos aspectos do senso comum, a campanha pretende passar a ideia que a reforma é um consenso entre todos os brasileiros, que é o único caminho para tirar o país da crise, que não haverá privilégios (todos serão tratados da mesma forma), que não há diferenças entre classes sociais e que os trabalhadores, sobretudo dos postos menos valorizados, concordam com a reforma (sem objeção). Esses são elementos que se caracterizam como ideológicos alinhados a uma perspectiva filosófica de senso comum. Dentre os elementos ideológicos destacam-se a universalização e o reducionismo da complexidade desse tema. Em primeiro lugar, pelo fato que universaliza que todos os brasileiros serão tratados da mesma forma, mas não esclarece as diversas formas de categorias de trabalhadores. Em segundo lugar, apaga as diferenças de classe social. A propaganda transmite a falsa ideia que não existem classes sociais no Brasil. Em terceiro lugar, utiliza-se de um reducionismo simbólico, ao propor que existe somente essa alternativa para o país. Esse ponto é percebido nas diversas afirmações (diálogos) que utilizam a expressão "né".

Em relação à ideologia e patriotismo, a propaganda de governo "Nova previdência" utiliza uma técnica amplamente presente em governos que buscam a aclamação popular. 
Basta lembrar-se do slogan publicitário na ditadura militar: "Brasil: Ame-o ou deixe-o!". A mesma técnica de ligar o patriotismo à aceitação de condições sociais, sem o contraditório, está presente na campanha de 2019. O simbolismo patriótico pretende produzir um sentido coletivo de aceitação, isto é, um ideal representado pelo objetivo: se você é brasileiro e ama esse país, deve aceitar a reforma da previdência, mesmo que isso custe sacrifícios. No mesmo caminho, a propaganda transmite a seguinte mensagem: quem é contra a reforma da previdência ou questiona seus termos é contra o país. Esse tipo de produção publicitária é ideológica, porque além de não informar, trabalha ideias, valores e sentimentos que não possuem causa e efeito, ou que acabam alimentando extremismos. Em outras palavras, utiliza elementos para convencer e produzir uma opinião pública favorável ao governo, mas não possui nexo ou interfaces com a realidade social. É possível aferir que na peça publicitária "Nova Previdência", o governo brasileiro se utiliza das categorias senso comum e ideologia e patriotismo e ideologia para produzir uma opinião pública favorável à reforma. Suas estratégias passaram pelo sentimento de patriotismo até a eliminação das contradições de classe social. Os sentimentos de otimismo e coesão social foram os fios condutores da peça publicitária.

Os elementos apresentados na propaganda do governo objetivam produzir uma opinião favorável. De acordo com Lippmann (2008), a sociedade não se funda na “comunhão", nem no "consenso", mas na "coincidência". Por isso, a opinião pública, seria fruto da ação de grupos de interessados ou de pessoas agindo em nome de grupos. A opinião reconhecida como pública, então, seria opiniões feitas públicas. E não opiniões derivadas do público. Neste caso, a propaganda de governo, pretende por meio de uma campanha publicitária tornar público os argumentos que legitimem a aprovação da reforma da previdência. O sentido da propagada governamental é solidificar uma compreensão coletiva que não apenas entenda como defenda a necessidade da reforma da previdência.

Portanto, a propaganda de governo "Nova previdência" apresenta uma roupagem informativa, mas que na prática atua para convencer por meio de técnicas e recursos ideológicos e simbólicos. O objetivo não é informar os impactos da reforma, mas convencer em grande escala, o cidadão brasileiro da necessidade da reforma da previdência. 


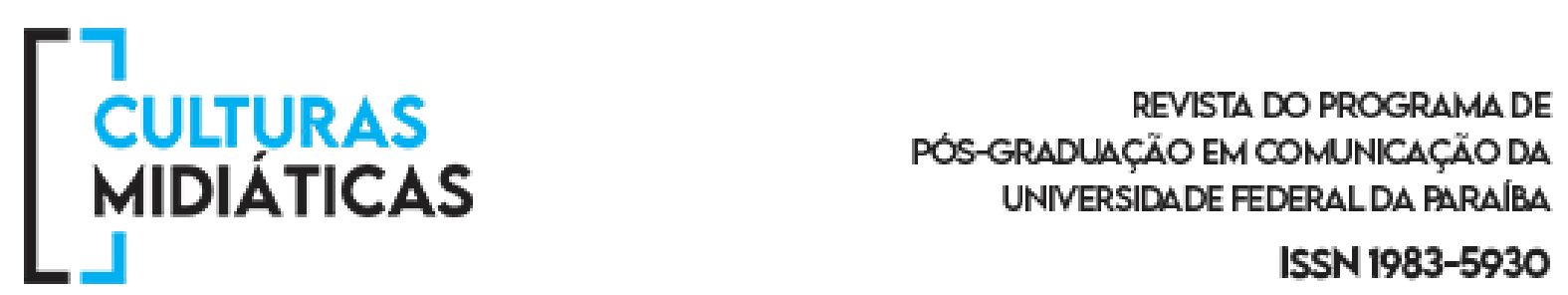

Por isso, esse tipo de propaganda é uma ferramenta utilizada pelos governos, mas que, na maioria das vezes, é alienante e produz uma concepção distorcida dos fatos e acontecimentos.

\section{REFERÊNCIAS}

ALTHUSSER, Louis. Aparelhos Ideológicos de Estado. 2. ed. Rio de Janeiro: Edições Graal, 1970.

BARDIN, Laurence. Análise de Conteúdo. São Paulo: Atlas, 2004.

BRANCO, Luís Alexandre Ribeiro. O pessimismo nacional. 2015. Disponível em: https://pt.scribd.com/read/235572210/O-Pessimismo-Nacional. Acesso em: 17 ago. 2019.

CHAUÍ, Marilena. Manifestações ideológicas do autoritarismo brasileiro. Belo Horizonte: Autêntica, 2013. Disponível em: https://pt.scribd.com/read/405798259/Manifestacoes-ideologicas-do-autoritarismobrasileiro-Escritos-de-Marilena-Chaui-vol-2. Acesso em: 03 ago. 2019.

CHAUÍ, Marilena. O que é ideologia? São Paulo: Editora e Livraria Brasiliense, 2017.

DEBOR, Guy. A sociedade do Espetáculo. São Paulo: Books Brasil, 1997.

DURAND, Jean-Pierre. A Sociologia de Marx. Petrópolis: Vozes, 2016. (Coleção Sociologia: Pontos de Referência).

GARCIA, Nelson Jahr. Propaganda: Ideologia e Manipulação. São Paulo: Rocket Edition, 1999.

GRAMSCI, Antonio. Cadernos do Cárcere. v.1. Rio de Janeiro: Civilização Brasileira, 1999.

FOLHA DE S. PAULO. $51 \%$ são contra a reforma da Previdência, indica Datafolha. Disponível em: https://www1.folha.uol.com.br/mercado/2019/04/51-sao-contra-reformada-previdencia-indica-datafolha.shtml. Acessado em: 25 set.2020.

KUJAWSKI, Gilberto de Mello. Patriotismo e nacionalismo. São Paulo: Massao Ohno, 1997.

LIPPMANN, Walter. Opinião Pública. Rio de Janeiro: Vozes, 2008. 


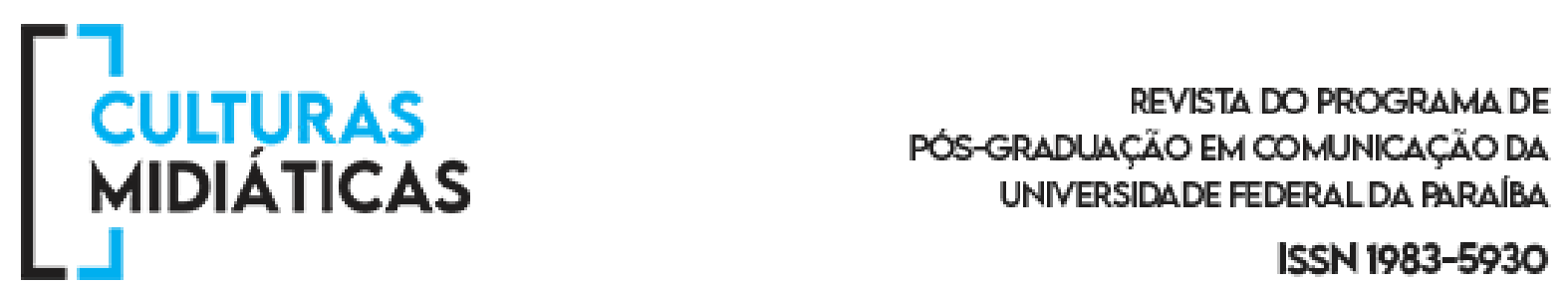

MANHANELLI, Carlos Augusto. Eleição é guerra: marketing para campanhas eleitorais. São Paulo: Summus, 1992.

MARX, Karl Heinrich; ENGELS, Friedrich. A ideologia alemã. Rocket Edition, 1999. Ebook.

PÊCHEUX, M. Apresentação da AAD. In: GADET, F.; HAK, H. Por uma análise automática do discurso (Uma introdução à obra de Michel Pêcheux). Campinas: Pontes, 1990.

PERELMAN, Chaim. Tratado da argumentação. 3. ed. São Paulo: Martins Fontes, 2014. SANT'ANNA, Armando. Propaganda: teoria, técnica e prática. 8. ed. São Paulo: Cengage Learning, 2009.

SECON. Secretaria Especial de Comunicação Social da Presidência da República. Disponível em: http://www.secom.gov.br. Acesso em: 04 fev. 2020.

THOMPSON, John B. A mídia e a modernidade: Uma teoria social da mídia. Petrópolis: Vozes, 1998.

THOMPSON, Jhon B. Ideologia e cultura moderna: teoria social crítica na era dos melos de comunicação de massa. 9. ed. Petrópolis: Vozes, 2011.

THOMPSON, John B.; BRANDÃO, Wagner de Oliveira. A mídia e a modernidade: uma teoria social da mídia. 7. ed. Rio de Janeiro: Vozes, 2005.

YOUTUBE. Governo do Brasil. Nova Previdência. 12 mar. 2019. 30s. Brasília, DF: Governo Federal. Disponível em: https://youtu.be/P0whGOzKzhk. Acesso em: 22 set. 2019. 


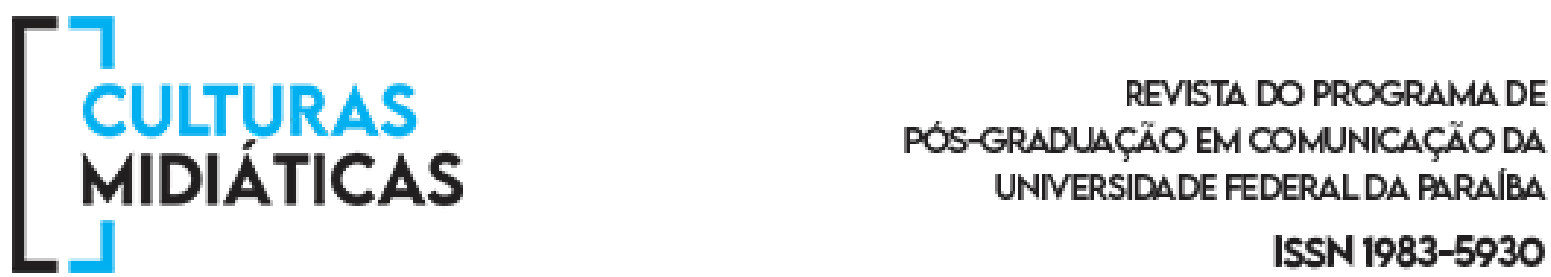

\section{COMO CITAR ESTE ARTIGO}

TREVISOL, Marcio Giusti; ALMEIDA, Maria de Lourdes Pinto de; OLEINICK, Natália. Aspectos ideológicos da peça publicitária "Nova Previdência". Revista Culturas Midiáticas, João Pessoa, v. 13, n. 2, pp. 75-95, 2020. DOI: https://doi.org/10.22478/ufpb.1983-5930.2020v13n2.55894. 